\title{
Past experience, 'shadow of the future', and patient trust: a cross-sectional survey
}

\author{
Carolyn Tarrant, Andrew M Colman and Tim Stokes
}

\begin{abstract}
Recent changes to the organisation and delivery of primary care in the UK have the potential to reduce continuity of care markedly, but it is not clear how this will have an impact on patient trust. This study aims to test the associations between specific aspects of continuity in the GP-patient relationship, and patient trust, informed by the theoretical framework of behavioural game theory. A cross-sectional survey of patients in three Leicestershire general practices was conducted. Regression analysis showed that ratings of the GP's interpersonal care, past experience of cooperation, and expectation of continuing care from the GP were all independent predictors of patient trust. These findings highlight the value of longitudinal aspects of the GP-patient relationship.

Keywords

continuity of patient care; cross-sectional studies; primary health care; trust.
\end{abstract}

\section{INTRODUCTION}

Trust is generally acknowledged to be a core component of the GP-patient relationship. It is important in its own right and it mediates other positive outcomes, including adherence to treatment. ${ }^{1}$ Recent changes to the organisation and delivery of primary care in the UK have the potential to reduce continuity of care markedly, ${ }^{2}$ as patients are increasingly likely to be consulting unfamiliar health professionals. It is not clear how this will have an impact on patient trust.

The limited research on the association between continuity and trust suggests that trust is promoted by the quality of the GP-patient relationship, and in particular the interpersonal aspects of the GP's care of the patient. ${ }^{3-6}$ There is a need to determine whether and how the longitudinal aspects of the GP-patient relationship affect patient trust.

This study uses a theoretical framework (behavioural game theory) as a basis for predictions about the specific aspects of continuity that promote trust. ${ }^{7}$ Game theory indicates that trust is promoted when people interact with each other repeatedly, and particularly when individuals are aware of their partners' cooperativeness on past occasions (either from personal experience or reputation), have a reputation for cooperativeness themselves, and anticipate ongoing interactions in the future - described as the 'shadow of the future'. ${ }^{8}$ Hence, game theory points to information about past cooperativeness, and an expectation of future interactions, as important determinants of trust.

This study aimed to test whether these dimensions of continuity, identified from game theory, are associated with patients' trust in GPs.

\section{METHOD}

A questionnaire was developed and piloted prior to use. The questionnaire included a series of questions on aspects of continuity, devised specially for this study. These questions were based on specific hypotheses derived from the framework of behavioural game theory. The questions on continuity consisted of statements accompanied by 
a five-point Likert scale labelled from strongly agree to strongly disagree. Evidence of cooperativeness in the past was assessed by the questions 'This GP has always given me the best possible treatment or advice in the past' and 'This GP knows, or has checked, whether I have followed the treatment or advice recommended on past occasions'. Anticipation of the future was assessed by the question 'This GP will follow up my progress in the future'. The questionnaire measured interpersonal care through the use of a single subscale from the General Practice Assessment Survey (GPAS) questionnaire (the 'interpersonal care' subscale), ${ }^{9}$ consisting of three questions asking patients to rate the amount of time the GP spent with them, the GP's patience, and caring and concern (Appendix 1, question 9). Trust was measured using the short form Interpersonal Trust in Physician Scale, ${ }^{10}$ which produces a trust score out of 100 (Appendix 1, question 10). The questionnaire was pretested through a postal pilot study involving 50 patients in a single GP practice, to assess response patterns and identify questions with very skewed responses or a large number of missing responses. Participants were asked for feedback on the content of the questionnaire. The questionnaire was revised as a result of this piloting.

The questionnaire was posted to a sample of 593 patients from three Leicestershire general practices (Appendix 2), in March and April 2005. Sample size was calculated from published guidelines for multiple regression analysis. ${ }^{11}$ Patients who had consulted at the practice over the past 2 weeks were selected at random from practice records, after excluding patients aged $<18$ years and $>75$ years. Data were analysed in SPSS using $t$ tests, Pearson's and point-biserial correlation, and multiple linear regression analysis (method: Enter).

\section{RESULTS}

The questionnaire was returned by 279 patients (47\%). Thirty-six patients did not see a GP at their most recent visit, but saw a practice nurse. These questionnaires were excluded, leaving 243 questionnaires for analysis. Characteristics of responders are given in Table 1.

The results of multiple regression analysis are shown in Table 2. Although patients who saw their usual GP had significantly higher trust scores than those who did not (83.5 compared to $72.6, t=3.53$, $P=0.001$ ), this did not emerge as an independent predictor of trust. Interpersonal care was the strongest predictor of trust. Good care from the GP in the past, belief that the GP knew or had checked whether the patient had followed the treatment or advice recommended on past occasions, and the

\section{How this fits in}

Patient trust is an important feature of primary care that may be threatened by reduced continuity of care resulting from new modes of delivery such as polyclinics. This study shows that positive ratings of a GP's interpersonal care, experiences of mutual cooperation between patient and GP in the past, and patients' expectations of continuing care from the same GP in the future are all associated with higher patient trust. This suggests that continuity of care and expectation of care from the same GP in the future are important in promoting patient trust.

patient's expectation that the GP would provide follow-up care in the future also emerged as significant independent predictors of trust.

The impact of patients' expectations of future care from the GP is underlined by the finding that patients who reported that the GP had asked them to come back and see him/her specifically in the future had higher trust scores than patients who had not been asked this by the GP (mean trust scores: 86.06 and 67.09 respectively, $t=5.65, P<0.001$ ).

\section{DISCUSSION}

\section{Summary of main findings}

Interpersonal care, information about past cooperation, and expectation of continuing care

\begin{tabular}{lc} 
Table 1. Characteristics of responders \\
( $\boldsymbol{n}=\mathbf{2 4 3 ) .}$ \\
Characteristic & $n(\%)$ \\
\hline Mean age, years (range, SD) & $50.0(18-75,15.84)$ \\
\hline Sex & \\
Male & $84(34.6)$ \\
Female & $157(64.6)$ \\
\hline Ethnicity, & \\
White British & $202(83.1)$ \\
White other & $12(4.9)$ \\
Indian & $14(5.8)$ \\
Pakistani & $3(1.2)$ \\
Black African/Caribbean & $4(1.6)$ \\
Other & $1(0.4)$ \\
\hline Employment status & \\
Employed & $117(48.2)$ \\
Retired & $60(24.7)$ \\
Unable to work due to illness & $24(9.9)$ \\
Looking after family & $17(7.0)$ \\
Other & $19(7.8)$ \\
\hline Health status & $17(7.0)$ \\
Excellent & $49(20.2)$ \\
Very good & $81(33.3)$ \\
Good & $64(26.3)$ \\
Fair & $28(11.5)$ \\
Poor & $135(55.6)$ \\
\hline Longstanding illness & $105(43.2)$ \\
Yes & \\
No & \\
SD = standard deviation. & \\
\hline & \\
\hline & \\
\hline
\end{tabular}


Table 2. Multiple linear regression analysis on trust score.

Standardised

\begin{tabular}{lcc} 
Standardised & $\begin{array}{c}\text { Correlation with } \\
\text { trust score }\end{array}$ & $\begin{array}{c}\text { regression coefficient } \\
(95 \% \mathrm{Cl})\end{array}$ \\
\hline Usual GP? (1 = no, 2 = yes) & $0.23^{\mathrm{b}}$ & $-0.01(-0.10$ to 0.08$)$ \\
\hline $\begin{array}{l}\text { Interpersonal care } \\
\begin{array}{l}\text { This GP knows or has checked whether } \\
\text { I have followed the treatment or advice } \\
\text { recommended on past occasions }\end{array}\end{array}$ & $0.77^{\mathrm{b}}$ & $0.47^{\mathrm{b}}(0.34$ to 0.60$)$ \\
\hline $\begin{array}{l}\text { This GP has always given me the best } \\
\text { possible treatment or advice in the past }\end{array}$ & $0.15^{\mathrm{c}}(0.01$ to 0.29$)$ \\
\hline \begin{tabular}{l} 
This GP will follow up my progress in the future \\
\hline Age
\end{tabular} & $0.69^{\mathrm{b}}$ & $0.10^{\mathrm{b}}(0.07$ to 0.33$)$ \\
\hline $\begin{array}{l}\text { Sex }(1=\text { male, } 2 \text { = female) } \\
\text { Ethnicity }(1=\text { white, } 2 \text { = other) }\end{array}$ & $0.20^{\mathrm{b}}$ & $-0.03(-0.12$ to 0.06$)$ \\
\hline
\end{tabular}

Adjusted $\mathrm{R}^{2}=0.70$. a Significant at $\mathrm{P}<0.001$. ${ }^{\text {b }}$ significant at $\mathrm{P}<0.05$. cCorrelation calculated is Pearson's $\mathrm{r}$, except for dichotomous variables (for example, sex), where the point biserial correlation $\left(r_{p b}\right)$ was used. from their GP in the future were all independent predictors of trust. Overall, these findings are in line with game theory predictions that positive experiences in past interactions (or evidence of past cooperative behaviour), and the 'shadow of the future', promote trust.

\section{Strengths and limitations of the study}

The following study limitations are noted. First, the survey involved a relatively small number of patients from three Leicestershire general practices, and the response rate was relatively low. Due to the method of sampling used, the sample may be over-inclusive of patients who had consulted full-time as opposed to part-time GPs. The percentage of female compared to male responders was relatively high, although this is common in surveys of primary care patients. Hence, the sample may not be fully representative of the population of the practices involved, and the generalisability of the findings may be correspondingly limited. Second, although significant findings emerged on the relationship between continuity and trust, it should be emphasised that this is a cross-sectional study, and it is not valid to infer causality from the findings.

\section{Comparison with existing literature}

Patients' rating of interpersonal care in the consultation was the strongest predictor of trust, as identified by previous research. ${ }^{3-6,12,13}$ Patients also had higher trust when they had experienced goodquality care in the past and when they felt the GP knew them to be a cooperative patient; previous research has reported that positive shared experiences in the past have an impact on trust. ${ }^{3,14}$ Patients also had higher trust when they believed the GP would follow them up in the future. Although trust has been conceptualised as 'forward looking and reflect[ing] a commitment to an ongoing relationship', ${ }^{15}$ this study is the first to provide empirical support for the association between anticipation of future care and trust.

Seeing the 'usual GP' did not emerge as an independent predictor in the regression analysis. The findings of this study indicate that trust is nuanced and is based on a range of evidence suggesting trust is warranted, including interpersonal aspects of the consultation, evidence of good care in the past, and evidence of commitment to future care. These findings suggest that seeing the 'usual GP' in itself is not sufficient to promote trust, but is likely to have value in that it provides an opportunity for past interactions to be judged as cooperative, ${ }^{3}$ and for future interactions to be anticipated with more certainty.

\section{Implications for clinical practice and future research}

The study findings merit exploration and development. The key finding is that longitudinal elements of continuity have an impact on patient trust, over and above the influence of the GP's interpersonal skills. Further empirical work should be undertaken to confirm this finding, and to test and explore 'anticipation of the future' as a dimension of continuity. Future research aiming to define and measure continuity should take note of the conceptualisation of continuity provided by game theory.

The study has important implications for practice. Although trust can be engendered outside of ongoing GP-patient relationships, the aspects of continuity of information and experience that were found to promote patient trust are more likely to feature when care is given by the same GP over time. This suggests that the current trend towards increased access and choice in primary care, at the expense of ongoing interpersonal continuity, may undermine patient trust. Ways of minimising this in primary care could include encouraging GPs to ask patients to come back to see them again personally, and putting practice systems in place to ensure that this is made easy for the patient (for example, flexible appointment booking systems). However, it should also be recognised that the shift towards providing primary care through alternative services, such as walk-in centres and polyclinics, may mean that opportunities for GPs and patients to build committed partnerships over time are lost.

\section{Funding body}

This study was partly funded through a grant from the University of Leicester Faculty of Medicine and Biological Sciences Research Committee 


\section{Ethical approval}

Ethical approval for the study was gained from the Leicestershire Research Ethics Committee

\section{Competing interests}

The authors have stated that there are none

\section{Acknowledgements}

The authors are grateful to the three general practices and the patients who took part in the study.

\section{Discuss this article}

Contribute and read comments about this article on the Discussion Forum: http://www.rcgp.org.uk/bjgp-discuss

\section{REFERENCES}

1. Thom DH, Kravitz RL, Bell RA, et al. Patient trust in the physician: relationship to patient requests. Fam Pract 2002; 19(5): 476-483.

2. Freeman GK, Olesen F, Hjortdahl P. Continuity of care: an essential element of modern general practice? Fam Pract 2003; 20: 623-627.

3. Caterinicchio RP. Testing plausible path models of interpersonal trust in patient-physician treatment relationships. Soc Sci Med 1979; 13A(1): 81-99.

4. Tarrant C, Stokes T, Baker R. Factors associated with patients' trust in their general practitioner: a cross-sectional survey. $\mathrm{Br} \mathrm{J} \mathrm{Gen}$ Pract 2003; 53(495): 798-800.

5. Thom DH, Ribisl KM, Steward AL, et al. Further validation and reliability testing of the trust in physician scale. Med Care 1999; 37(5): 510-517.

6. Safran DG, Kosinski M, Tarlov AR, et al. The Primary Care Assessment Survey: tests of data quality and measurement performance. Med Care 1998; 36(5): 728-739.

7. Tarrant C, Stokes T, Colman AM. Models of the medical consultation: opportunities and limitations of a game theory perspective. Qual Saf Health Care 2004; 13(6): 461-466.

8. Axelrod R. The evolution of cooperation. New York: Basic Books, 1984.

9. Schroter S, Green J, Roland M, et al. The General Practice Assessment Survey (GPAS): tests of data quality and measurement properties. Fam Pract 2000; 17(5): 372-379.

10. Dugan E, Trachtenberg F, Hall MA. Development of abbreviated measures to assess patient trust in a physician, a health insurer, and the medical profession. BMC Health Serv Res 2005; 5: 64.

11. Green SB. How many subjects does it take to do a regression analysis? Multivar Behav Res 1991; 26: 499-510.

12. Thom DH, Campbell B. Patient-physician trust: an explanatory study. J Fam Pract 1997; 44(2): 169-176.

13. Mechanic D, Meyer S. Concepts of trust among patients with serious illness. Soc Sci Med 2000; 51(5): 657-668.

14. Mainous AG III, Goodwin MA, Stange KC. Patient-physician shared experiences and value patients place on continuity of care. Ann Fam Med 2004; 2(5): 452-454.

15. Calnan M, Rowe R. Trust in health care: an agenda for future research. London: The Nuffield Trust, 2004; 5 . 


\section{Appendix 1. Full questionnaire.}

Patients' experiences of visiting the GP or nurse

- This questionnaire is confidential. Your doctor will not get to know what you have said in the questionnaire.

- This questionnaire asks about your most recent visit to a GP (family doctor) or nurse from your GP practice. If you do not want to answer a question, leave it blank and move on to the next one.

- The following questions are about your most recent visit to a GP or nurse from your GP practice.

1. Who was this most recent visit for? (tick any that apply)

Self

Child

2. Was the reason for your most recent visit to do with (tick any that apply)

a problem or condition you had consulted about in the past a new problem, condition or procedure

3. Was the visit for something you considered urgent or not?

Yes, I considered it urgent

No, I did not consider it urgent

4. Did you make an appointment for the visit?

Yes, I made an appointment at least a day before the visit

Yes, I made an appointment on the same day as the visit

No, I just turned up for the visit

5a. Who did you see? (tick any that apply)

A GP (family doctor)

A practice nurse

5b. If you saw a GP was this:

A GP who usually works at your practice?

A GP who does not usually work at your practice (for example, a registrar/ locum)?

The following questions are about the GP or nurse you saw on your most recent visit. If you saw a GP and a nurse, please answer the following questions about the GP.

6a. Have you been to see this GP/nurse before?

Yes

No (if no, go to question 7)

$6 \mathrm{~b}$. Is this the person you usually see?

Yes

No (if no, go to question 7)

6c. How long have you been with this GP/nurse?

Less than 6 months

More than 6 months but less than a year

At least 1 year but less than 5 years

At least 5 years but less than 10 years

10 years or more

Can't remember

Can't remember 


\section{Appendix 1. Full questionnaire continued.}

7. Please tick a box to indicate the extent to which you agree or disagree with each of the following statements:

a. This GP/nurse remembers me when I visit.

\begin{tabular}{|c|c|c|c|c|c|}
\hline $\begin{array}{l}\text { Strongly } \\
\text { disagree }\end{array}$ & & & & $\begin{array}{c}\text { Strongly } \\
\text { agree }\end{array}$ & $\begin{array}{r}\text { Don't know/ } \\
\text { not applicable }\end{array}$ \\
\hline$\square 1$ & $\square 2$ & $\square 3$ & $\square 4$ & $\square 5$ & \\
\hline
\end{tabular}

b. This GP/nurse knows, or has checked, whether I have followed the treatment or advice recommended on past occasions.

\begin{tabular}{|c|c|c|}
\hline $\begin{array}{l}\text { Strongly } \\
\text { disagree }\end{array}$ & & \\
\hline$\square 1$ & $\square 2$ & $\square 3$ \\
\hline
\end{tabular}

c. This GP/nurse has always given me the best possible treatment or advice in the past.

$\begin{array}{lllcr}\begin{array}{l}\text { Strongly } \\ \text { disagree }\end{array} & \text { Strongly } & \begin{array}{r}\text { Don't know/ } \\ \text { agree } \\ \text { not applicable }\end{array} \\ \square 1 & \square 2 & \square 3 & \square 4 & \square 5\end{array}$

d. This GP/nurse has a very good reputation with patients.

$\begin{array}{lllrl}\text { Strongly } & & \text { Strongly } & \text { Don't know/ } \\ \text { disagree } & \square 2 & \text { agree } & \text { not applicable } \\ \square 1 & \square 3 & \square 4 & \square 5 & \square 0\end{array}$

e. On this occasion, I feel sure that this GP/nurse gave me the best possible treatment or advice.

$\begin{array}{llcr}\text { Strongly } & & \text { Strongly } & \text { Don't know/ } \\ \text { disagree } & \square 2 & \text { agree } & \text { not applicable } \\ \square 1 & \square 3 & \square 4 & \square 5\end{array}$

f. I would like to see this $\mathrm{GP} /$ nurse next time I visit.

\begin{tabular}{|c|c|c|c|c|}
\hline $\begin{array}{l}\text { Strongly } \\
\text { disagree }\end{array}$ & & & & $\begin{array}{l}\text { Strongly } \\
\text { agree }\end{array}$ \\
\hline$\square 1$ & $\square 2$ & $\square 3$ & $\square 4$ & $\square 5$ \\
\hline
\end{tabular}

g. I expect that I will see this GP/nurse next time I visit.

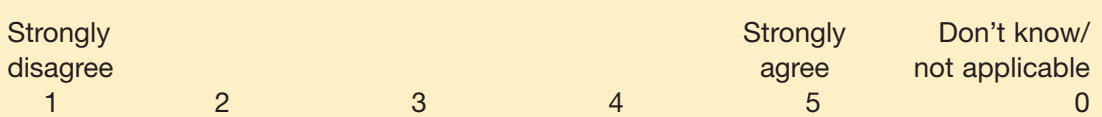

h. It will be easy for me to get to see this GP/nurse again in the future.

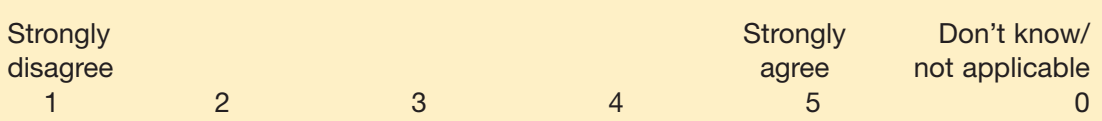

i. I expect that I will continue to see this GP/nurse for the foreseeable future.

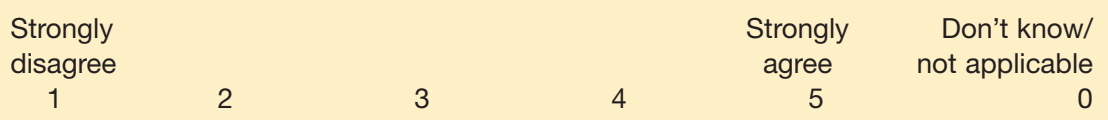

j. This GP/nurse will get to know whether I have followed their treatment or advice.

\begin{tabular}{|c|c|c|c|c|}
\hline $\begin{array}{l}\text { Strongly } \\
\text { disagree }\end{array}$ & & & & $\begin{array}{l}\text { Strongly } \\
\text { agree }\end{array}$ \\
\hline$\square 1$ & 2 & 3 & $\square 4$ & $\square 5$ \\
\hline
\end{tabular}

k. This GP/nurse will follow up my progress in the future.

\begin{tabular}{|c|c|c|c|c|c|}
\hline $\begin{array}{l}\text { Strongly } \\
\text { disagree }\end{array}$ & & & & $\begin{array}{l}\text { Strongly } \\
\text { agree }\end{array}$ & $\begin{array}{l}\text { Don't know/ } \\
\text { not applicable }\end{array}$ \\
\hline$\square 1$ & $\square 2$ & $\square 3$ & $\square 4$ & $\square 5$ & \\
\hline
\end{tabular}




\section{Appendix 1. Full questionnaire continued.}

8a. On this occasion, did the GP/nurse ask you to come back again if you had any problems?

Yes

No (if no, go to question 9)

8b. If yes, did the GP/nurse ask you to come back to see:

Him/her specifically $\quad \square 1$

Any of the practice GPs/nurses $\quad \square 2$

9. Thinking about your most recent visit, how do you rate the following:

a. the amount of time the GP/nurse spent with you?

$\begin{array}{cccccr}\text { Very poor } & \text { Poor } & \text { Fair } & \text { Good } & \text { Very good } & \text { Excellent } \\ \square 1 & \square 2 & \square 3 & \square 4 & \square 5 & \square 6\end{array}$

b. The GP/nurse's patience with your questions or worries?

$\begin{array}{cccccr}\text { Very poor } & \text { Poor } & \text { Fair } & \text { Good } & \text { Very good } & \text { Excellent } \\ \square 1 & \square 2 & \square 3 & \square 4 & \square 5 & \square 6\end{array}$

c. The GP/nurse's caring and concern for you?

$\begin{array}{cccccr}\text { Very poor } & \text { Poor } & \text { Fair } & \text { Good } & \text { Very good } & \text { Excellent } \\ \square 1 & \square 2 & \square 3 & \square 4 & \square 5 & \square 6\end{array}$

10. Please tick a box to indicate the extent to which you agree or disagree with each of the following statements:

a. Sometimes this GP/nurse cares more about what is convenient for him/her than about your medical needs.

$\begin{array}{ccccc}\text { Strongly } & & \begin{array}{c}\text { Strongly } \\ \text { agree }\end{array} & \begin{array}{r}\text { Don't know/ } \\ \text { not applicable }\end{array} \\ \square 1 & \square 2 & \square 3 & \square 4 & 5\end{array}$

b. This GP/nurse is extremely thorough and careful.

$\begin{array}{ccccc}\begin{array}{l}\text { Strongly } \\ \text { disagree }\end{array} & \begin{array}{c}\text { Strongly } \\ \text { agree }\end{array} & \begin{array}{r}\text { Don't know/ } \\ \text { not applicable }\end{array} \\ \square 1 & \square 2 & \square 3 & \square 4 & 5\end{array}$

c. This GP/nurse is totally honest in telling you about all of the different treatment options available for your condition.
Strongly
disagree
$\square 2$
$\square 3$
Strongly Don't know/ agree not applicable $\square 5$
$\square 0$

d. You completely trust this GP/nurse's decisions about which medical treatments are best for you.

$\begin{array}{ccccc}\begin{array}{c}\text { Strongly } \\ \text { disagree }\end{array} & \begin{array}{c}\text { Strongly } \\ \text { agree }\end{array} & \begin{array}{r}\text { Don't know/ } \\ \text { not applicable }\end{array} \\ \square 1 & \square 2 & \square 3 & \square 4 & \square\end{array}$

e. All in all you have complete trust in this GP/nurse.

\section{Strongly \\ disagree}

$\square 1$

$\square 2$

$\square 3$

$\square 4$

Strongly agree

$\square 5$
Don't know/ not applicable

11. All things considered, how much did you trust this GP/nurse?
Not at all
$\square 1$
$\square 2$
$\square 3$
$\square 4$
$\square 5$
$\square$
$\square 7$
$\square 8$
Completely
$9 \quad \square$ 


\section{Appendix 1. Full questionnaire continued.}

The following questions are about the treatment or advice you were given on your most recent visit

12a. On this occasion did you get a prescription?

Yes

No (if no, go to question 13a.)

12b. Have you taken the medication?

Yes

Yes, but not exactly as prescribed

(for example, did not take all the tablets, took a lower dose)

No, not at all

12c. If you have not taken the medication at all, or have not taken it as prescribed, please say why not:

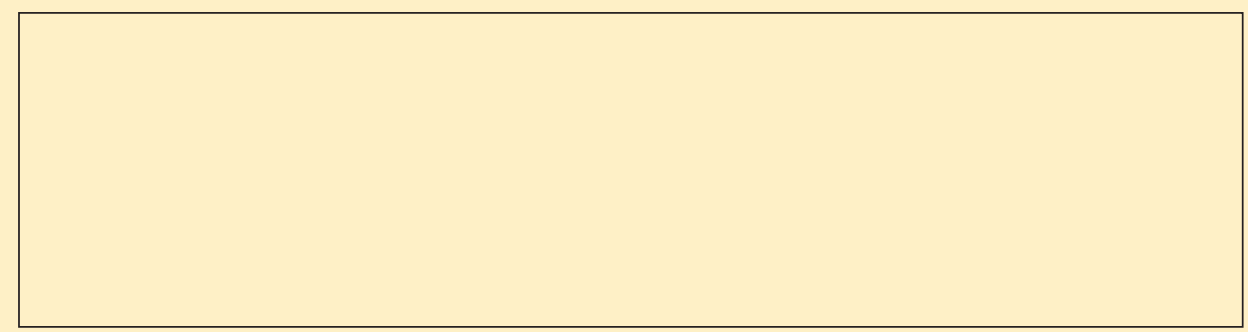

13a. To what extent have you followed the treatment or advice recommended by the GP/nurse on this occasion?
I have not followed
the treatment
the treatment or
or advice at all advice exactly as
$\square 1 \quad \square 2$
$\square 3 \quad \square 4$
$\square 5$
$\square 6$
$\square 7$
$\square 8$
recommended

have followed

13b. Please tick a box to indicate the extent to which you agree or disagree with the following statement:

I would follow any treatment or advice this GP/nurse recommended, even if I did not really want to.
Strongly disagree
$\square 1 \quad \square 2$
$\square 3$
Strongly agree
$\square 4 \quad \square 5$ 


\section{Appendix 1. Full questionnaire continued.}

The following questions are about you and your health

These questions are being asked to find out whether the questionnaire is completed by a wide range of different people.

14. Are you:

Male $\quad \square 1$

Female $\quad \square 2$

15. What is your age? years

16. Please tell us to which grouping you feel you belong.
If you prefer not to give this information please tick this box
$\square 0 \quad$ and go to question 17 .

$\begin{array}{lrlr}\text { White English, Scottish, Welsh or Irish } \square 1 & \text { Black Caribbean } & \square 6 \\ \text { White other } & \square 2 & \text { Black African } & \square 7 \\ \text { Indian } & \square 3 & \text { Chinese } & \square 8 \\ \text { Pakistani } & \square 4 & \text { Other (please specify) } & \square 9 \\ \text { Bangladeshi } & \square 5 & & \end{array}$

17. How would you describe your current situation regarding employment?

$\begin{array}{llll}\text { Employed full time } & \square 1 & \text { Unable to work due to ill } & \square 6 \\ \text { Employed part time } & \square 2 & \text { health or disability } & \\ \text { Self employed } & \square 3 & \text { Looking after the family, home } & \square 7 \\ \text { Unemployed } & \square 4 & \text { or dependants } & \\ \text { Retired } & \square 5 & \text { Student } & \square 8 \\ & & \text { Other } & \square 9\end{array}$

18. Is the house/flat/other place where you live:

Owned by you (including with a mortgage)?

Rented or other arrangements?

19. Over the past 12 months, how would you say your health has been:
Excellent?
Very good?
Good?
Fair?
Poor

20. Over the past 12 months, have you suffered from any long-standing illness, health problem or disability?
Yes No

21. Over the past 12 months, approximately how many times have you been to see a GP or nurse about your health?

1 or 2 times

3 to 6 times

7 to 12 times

3

more than 12 times

THANK YOU VERY MUCH FOR COMPLETING THIS QUESTIONNAIRE.

Please return the questionnaire in the envelope provided. No stamp is needed. 


\section{Appendix 2. Characteristics of participating practices.}

\begin{tabular}{lcccc} 
& Locality & Number of partners & List size & Deprivation $^{\text {a }}$ \\
\hline Practice 1 & Inner city & Medium $(5-7)$ & $12000+$ & High \\
\hline Practice 2 & Urban & Medium $(5-7)$ & $6000-12000$ & High \\
\hline Practice 3 & Market town & Large $(>7)$ & $12000+$ & Moderate \\
\hline
\end{tabular}

${ }^{a}$ Based on Townsend Score: Townsend P, Phillimore $P$, Bealtie A. Health and deprivation: inequality and the north. London: Croom Helm, 1988. 